\title{
3A. Estrogen receptors (version 2019.4) in the IUPHAR/BPS Guide to Pharmacology Database
}

\author{
Laurel Coons ${ }^{1}$ and Kenneth S. Korach ${ }^{2}$
}

1. Duke University, USA

2. National Institutes of Health, USA

\begin{abstract}
Estrogen receptor (ER) activity regulates diverse physiological processes via transcriptional modulation of target genes. The selection of target genes and the magnitude of the response, be it induction or repression, are determined by many factors, including the effect of the hormone ligand and DNA binding on ER structural conformation, and the local cellular regulatory environment. The cellular environment defines the specific complement of DNA enhancer and promoter elements present and the availability of coregulators to form functional transcription complexes. Together, these determinants control the resulting biological response.
\end{abstract}

\section{Contents}

This is a citation summary for 3A. Estrogen receptors in the Guide to Pharmacology database (GtoPdb). It exists purely as an adjunct to the database to facilitate the recognition of citations to and from the database by citation analyzers. Readers will almost certainly want to visit the relevant sections of the database which are given here under database links.

GtoPdb is an expert-driven guide to pharmacological targets and the substances that act on them. GtoPdb is a reference work which is most usefully represented as an on-line database. As in any publication this work should be appropriately cited, and the papers it cites should also be recognized. This document provides a citation for the relevant parts of the database, and also provides a reference list for the research cited by those parts.

Please note that the database version for the citations given in GtoPdb are to the most recent preceding version in which the family or its subfamilies and targets were substantially changed. The links below are to the current version. If you need to consult the cited version, rather than the most recent version, please contact the GtoPdb curators.

\section{Database links}

\section{A. Estrogen receptors}

http://www.guidetopharmacology.org/GRAC/FamilyDisplayForward?familyld=96

Introduction to 3A. Estrogen receptors

http://www.guidetopharmacology.org/GRAC/FamilylntroductionForward?familyld=96

\section{Receptors}

Estrogen receptor- $\alpha$ 
http://www.guidetopharmacology.org/GRAC/ObjectDisplayForward?objectld=620

Estrogen receptor- $\beta$

http://www.guidetopharmacology.org/GRAC/ObjectDisplayForward?objectld=621

\section{References}

1. Auerbach SS and DrugMatrix ${ }^{\circledR}$ and ToxFX ${ }^{\circledR}$ Coordinator National Toxicology Program.. National Toxicology Program: Dept of Health and Human Services.

2. Barkhem T, Haldosén LA, Gustafsson JA and Nilsson S. (2002) pS2 Gene expression in HepG2 cells: complex regulation through crosstalk between the estrogen receptor alpha, an estrogen-responsive element, and the activator protein 1 response element. Mol. Pharmacol. 61: 1273-83 [PMID:12021387]

3. Burke C. (2005) Endometrial cancer and tamoxifen. Clin J Oncol Nurs 9: 247-9 [PMID:15853168]

4. Chao EY, Collins JL, Gaillard S, Miller AB, Wang L, Orband-Miller LA, Nolte RT, McDonnell DP, Willson TM and Zuercher WJ. (2006) Structure-guided synthesis of tamoxifen analogs with improved selectivity for the orphan ERRgamma. Bioorg. Med. Chem. Lett. 16: 821-4 [PMID:16307879]

5. Chu S and Fuller PJ. (1997) Identification of a splice variant of the rat estrogen receptor beta geneMol. Cell. Endocrinol. 132: 195-9 [PMID:9324061]

6. Couse JF, Dixon D, Yates M, Moore AB, Ma L, Maas R and Korach KS. (2001) Estrogen receptor-alpha knockout mice exhibit resistance to the developmental effects of neonatal diethylstilbestrol exposure on the female reproductive tract. Dev. Biol. 238: 224-38 [PMID:11784006]

7. Cvoro A, Tatomer D, Tee MK, Zogovic T, Harris HA and Leitman DC. (2008) Selective estrogen receptorbeta agonists repress transcription of proinflammatory genes. J. Immunol. 180: 630-6 [PMID:18097065]

8. Dahlman-Wright K, Cavailles V, Fuqua SA, Jordan VC, Katzenellenbogen JA, Korach KS, Maggi A, Muramatsu M, Parker MG and Gustafsson JA. (2006) International Union of Pharmacology. LXIV. Estrogen receptors. Pharmacol. Rev. 58: 773-81 [PMID:17132854]

9. de Koning J, Lambalk CB, Helmerhorst FM and Helder MN. (2001) Is GnRH self-priming an obligatory feature of the reproductive cycle? Hum. Reprod. 16: 209-14 [PMID:11157808]

10. Delfosse V, Grimaldi M, Pons JL, Boulahtouf A, le Maire A, Cavailles V, Labesse G, Bourguet W and Balaguer P. (2012) Structural and mechanistic insights into bisphenols action provide guidelines for risk assessment and discovery of bisphenol A substitutes. Proc. Natl. Acad. Sci. U.S.A. 109: 14930-5 [PMID:22927406]

11. Devin-Leclerc J, Meng X, Delahaye F, Leclerc P, Baulieu EE and Catelli MG. (1998) Interaction and dissociation by ligands of estrogen receptor and Hsp90: the antiestrogen RU 58668 induces a protein synthesis-dependent clustering of the receptor in the cytoplasm. Mol. Endocrinol. 12: 842-54 [PMID:9626660]

12. Escande A, Servant N, Rabenoelina F, Auzou G, Kloosterboer H, Cavaillès V, Balaguer $P$ and Maudelonde T. (2009) Regulation of activities of steroid hormone receptors by tibolone and its primary metabolites. J. Steroid Biochem. Mol. Biol. 116: 8-14 [PMID:19464167]

13. Flouriot G, Brand H, Denger S, Metivier R, Kos M, Reid G, Sonntag-Buck V and Gannon F. (2000) Identification of a new isoform of the human estrogen receptor-alpha (hER-alpha) that is encoded by distinct transcripts and that is able to repress hER-alpha activation function 1. EMBO J. 19: 4688-700 [PMID:10970861]

14. Fuqua SA, Wiltschke C, Zhang QX, Borg A, Castles CG, Friedrichs WE, Hopp T, Hilsenbeck S, Mohsin S, O'Connell P and Allred DC. (2000) A hypersensitive estrogen receptor-alpha mutation in premalignant breast lesions. Cancer Res. 60: 4026-9 [PMID:10945602]

15. Germain P, Staels B, Dacquet C, Spedding M and Laudet V. (2006) Overview of nomenclature of nuclear receptors. Pharmacol. Rev. 58: 685-704 [PMID:17132848]

16. Greene GL, Gilna P, Waterfield M, Baker A, Hort Y and Shine J. (1986) Sequence and expression of human estrogen receptor complementary DNA. Science 231: 1150-4 [PMID:3753802]

17. Hall DA, Beresford IJ, Browning C and Giles H. (1999) Signalling by CXC-chemokine receptors 1 and 2 expressed in $\mathrm{CHO}$ cells: a comparison of calcium mobilization, inhibition of adenylyl cyclase and 
stimulation of GTPgammaS binding induced by IL-8 and GROalpha. Br. J. Pharmacol. 126: 810-8 [PMID:10188995]

18. Hall JM and Korach KS. (2002) Analysis of the molecular mechanisms of human estrogen receptors alpha and beta reveals differential specificity in target promoter regulation by xenoestrogens. J. Biol. Chem. 277: 44455-61 [PMID:12200415]

19. Hall JM and McDonnell DP. (2005) Coregulators in nuclear estrogen receptor action: from concept to therapeutic targeting. Mol. Interv. 5: 343-57 [PMID:16394250]

20. Henke BR, Drewry DH, Jones SA, Stewart EL, Weaver SL and Wiethe RW. (2001) 2-Amino-4,6diarylpyridines as novel ligands for the estrogen receptor. Bioorg. Med. Chem. Lett. 11: 1939-42 [PMID:11459665]

21. Hughes ZA, Liu F, Platt BJ, Dwyer JM, Pulicicchio CM, Zhang G, Schechter LE, Rosenzweig-Lipson S and Day M. (2008) WAY-200070, a selective agonist of estrogen receptor beta as a potential novel anxiolytic/antidepressant agent. Neuropharmacology 54: 1136-42 [PMID:18423777]

22. Jain N, Kanojia RM, Xu J, Jian-Zhong G, Pacia E, Lai MT, Du F, Musto A, Allan G and Hahn Det al.. (2006) Novel chromene-derived selective estrogen receptor modulators useful for alleviating hot flushes and vaginal dryness. J. Med. Chem. 49: 3056-9 [PMID:16722623]

23. Kim SS, Kwack SJ, Lee RD, Lim KJ, Rhee GS, Seok JH, Kim BH, Won YH, Lee GS, Jeung EB, Lee BM and Park KL. (2005) Assessment of estrogenic and androgenic activities of tetramethrin in vitro and in vivo assays. J. Toxicol. Environ. Health Part A68: 2277-89 [PMID:16326440]

24. Koike S, Sakai M and Muramatsu M. (1987) Molecular cloning and characterization of rat estrogen receptor cDNA. Nucleic Acids Res. 15: 2499-513 [PMID:3031601]

25. Kraichely DM, Sun J, Katzenellenbogen JA and Katzenellenbogen BS. (2000) Conformational changes and coactivator recruitment by novel ligands for estrogen receptor-alpha and estrogen receptor-beta: correlations with biological character and distinct differences among SRC coactivator family members. Endocrinology 141: 3534-45 [PMID:11014206]

26. Kuiper GG, Carlsson B, Grandien K, Enmark E, Häggblad J, Nilsson S and Gustafsson JA. (1997) Comparison of the ligand binding specificity and transcript tissue distribution of estrogen receptors alpha and beta. Endocrinology 138: 863-70 [PMID:9048584]

27. Kuiper GG, Enmark E, Pelto-Huikko M, Nilsson S and Gustafsson JA. (1996) Cloning of a novel receptor expressed in rat prostate and ovary. Proc. Natl. Acad. Sci. U.S.A. 93: 5925-30 [PMID:8650195]

28. Lewis JS and Jordan VC. (2005) Selective estrogen receptor modulators (SERMs): mechanisms of anticarcinogenesis and drug resistance. Mutat. Res. 591: 247-63 [PMID:16083919]

29. Malamas MS, Manas ES, McDevitt RE, Gunawan I, Xu ZB, Collini MD, Miller CP, Dinh T, Henderson RA and Keith JC et al.. (2004) Design and synthesis of aryl diphenolic azoles as potent and selective estrogen receptor-beta ligands. J. Med. Chem. 47: 5021-40 [PMID:15456246]

30. Maruyama K, Nakamura M, Tomoshige S, Sugita K, Makishima M, Hashimoto Y and Ishikawa M. (2013) Structure-activity relationships of bisphenol $A$ analogs at estrogen receptors (ERs): discovery of an ER $\alpha$ selective antagonist. Bioorg. Med. Chem. Lett. 23: 4031-6 [PMID:23768907]

31. McFarland K, Price DL, Davis CN, Ma JN, Bonhaus DW, Burstein ES and Olsson R. (2013) AC-186, a selective nonsteroidal estrogen receptor $\beta$ agonist, shows gender specific neuroprotection in a Parkinson's disease rat model. ACS Chem Neurosci 4: 1249-55 [PMID:23898966]

32. Mersereau JE, Levy N, Staub RE, Baggett S, Zogovic T, Zogric T, Chow S, Ricke WA, Tagliaferri M and Cohen I et al.. (2008) Liquiritigenin is a plant-derived highly selective estrogen receptor beta agonist.Mol. Cell. Endocrinol. 283: 49-57 [PMID:18177995]

33. Meyers MJ, Sun J, Carlson KE, Katzenellenbogen BS and Katzenellenbogen JA. (1999) Estrogen receptor subtype-selective ligands: asymmetric synthesis and biological evaluation of cis- and trans-5,11-dialkyl5,6,11, 12-tetrahydrochrysenes. J. Med. Chem. 42: 2456-68 [PMID:10395487]

34. Meyers MJ, Sun J, Carlson KE, Marriner GA, Katzenellenbogen BS and Katzenellenbogen JA. (2001) Estrogen receptor-beta potency-selective ligands: structure-activity relationship studies of diarylpropionitriles and their acetylene and polar analogues. J. Med. Chem. 44: 4230-51 [PMID:11708925] 
35. Miller CP, Collini MD, Tran BD, Harris HA, Kharode YP, Marzolf JT, Moran RA, Henderson RA, Bender RH and Unwalla RJ et al.. (2001) Design, synthesis, and preclinical characterization of novel, highly selective indole estrogens. J. Med. Chem. 44: 1654-7 [PMID:11356100]

36. Minutolo F, Bertini S, Granchi C, Marchitiello T, Prota G, Rapposelli S, Tuccinardi T, Martinelli A, Gunther JR and Carlson KE et al.. (2009) Structural evolutions of salicylaldoximes as selective agonists for estrogen receptor beta. J. Med. Chem. 52: 858-67 [PMID:19128016]

37. Ning M, Zhou C, Weng J, Zhang S, Chen D, Yang C, Wang H, Ren J, Zhou L and Jin Cet al.. (2007) Biological activities of a novel selective oestrogen receptor modulator derived from raloxifene (Y134). Br. J. Pharmacol. 150: 19-28 [PMID:17115070]

38. Ogawa S, Inoue S, Watanabe T, Hiroi H, Orimo A, Hosoi T, Ouchi Y and Muramatsu M. (1998) The complete primary structure of human estrogen receptor beta (hER beta) and its heterodimerization with ER alpha in vivo and in vitro. Biochem. Biophys. Res. Commun. 243: 122-6 [PMID:9473491]

39. Ogawa S, Inoue S, Watanabe T, Orimo A, Hosoi T, Ouchi Y and Muramatsu M. (1998) Molecular cloning and characterization of human estrogen receptor betacx: a potential inhibitor ofestrogen action in human. Nucleic Acids Res. 26: 3505-12 [PMID:9671811]

40. Petz LN, Ziegler YS, Schultz JR, Kim H, Kemper JK and Nardulli AM. (2004) Differential regulation of the human progesterone receptor gene through an estrogen response element half site and Sp1 sites. J. Steroid Biochem. Mol. Biol. 88: 113-22 [PMID:15084343]

41. Renaud J, Bischoff SF, Buhl T, Floersheim P, Fournier B, Geiser M, Halleux C, Kallen J, Keller H and Ramage P. (2005) Selective estrogen receptor modulators with conformationally restricted side chains. Synthesis and structure-activity relationship of ERalpha-selective tetrahydroisoquinoline ligands. J. Med. Chem. 48: 364-79 [PMID:15658851]

42. Rosenfeld CS, Roberts RM and Lubahn DB. (2001) Estrogen receptor- and aromatase-deficient mice provide insight into the roles of estrogen within the ovary and uterus. Mol. Reprod. Dev. 59: 336-46 [PMID:11424220]

43. Safe S. (2001) Transcriptional activation of genes by 17 beta-estradiol through estrogen receptor-Sp1 interactions. Vitam. Horm. 62: 231-52 [PMID:11345900]

44. Schmidt JM, Mercure J, Tremblay GB, Pagé M, Kalbakji A, Feher M, Dunn-Dufault R, Peter MG and Redden PR. (2003) De novo design, synthesis, and evaluation of novel nonsteroidal phenanthrene ligands for the estrogen receptor. J. Med. Chem. 46: 1408-18 [PMID:12672240]

45. Shiau AK, Barstad D, Loria PM, Cheng L, Kushner PJ, Agard DA and Greene GL. (1998) The structural basis of estrogen receptor/coactivator recognition and the antagonism of this interaction by tamoxifen. Cell 95: 927-37 [PMID:9875847]

46. Shiau AK, Barstad D, Radek JT, Meyers MJ, Nettles KW, Katzenellenbogen BS, Katzenellenbogen JA, Agard DA and Greene GL. (2002) Structural characterization of a subtype-selective ligand reveals a novel mode of estrogen receptor antagonism. Nat. Struct. Biol. 9: 359-64 [PMID:11953755]

47. Simpson E, Jones M, Misso M, Hewitt K, Hill R, Maffei L, Carani C and Boon WC. (2005) Estrogen, a fundamental player in energy homeostasis. J. Steroid Biochem. Mol. Biol. 95: 3-8 [PMID:16054355]

48. Stauffer SR, Coletta CJ, Tedesco R, Nishiguchi G, Carlson K, Sun J, Katzenellenbogen BS and Katzenellenbogen JA. (2000) Pyrazole ligands: structure-affinity/activity relationships and estrogen receptor-alpha-selective agonists. J. Med. Chem. 43: 4934-47 [PMID:11150164]

49. Sun J, Huang YR, Harrington WR, Sheng S, Katzenellenbogen JA and Katzenellenbogen BS. (2002) Antagonists selective for estrogen receptor alpha. Endocrinology 143: 941-7 [PMID:11861516]

50. Sun J, Meyers MJ, Fink BE, Rajendran R, Katzenellenbogen JA and Katzenellenbogen BS. (1999) Novel ligands that function as selective estrogens or antiestrogens for estrogen receptor-alpha or estrogen receptor-beta. Endocrinology 140: 800-4 [PMID:9927308]

51. Teyssier C, Belguise K, Galtier F and Chalbos D. (2001) Characterization of the physical interaction between estrogen receptor alpha and JUN proteins. J. Biol. Chem. 276: 36361-9 [PMID:11477071]

52. Tremblay GB, Tremblay A, Copeland NG, Gilbert DJ, Jenkins NA, Labrie F and Giguère V. (1997) Cloning, chromosomal localization, and functional analysis of the murine estrogen receptor beta. Mol. Endocrinol. 
11: 353-65 [PMID:9058381]

53. Walker VR and Korach KS. (2004) Estrogen receptor knockout mice as a model for endocrine research. ILAR J 45: 455-61 [PMID:15454684]

54. Wang F, Porter W, Xing W, Archer TK and Safe S. (1997) Identification of a functional imperfect estrogenresponsive element in the 5'-promoter region of the human cathepsin D gene. Biochemistry 36: 7793-801 [PMID:9201922]

55. Waters EM, Mitterling K, Spencer JL, Mazid S, McEwen BS and Milner TA. (2009) Estrogen receptor alpha and beta specific agonists regulate expression of synaptic proteins in rat hippocampus. Brain Res. 1290: 1-11 [PMID:19596275]

56. White R, Lees JA, Needham M, Ham J and Parker M. (1987) Structural organization and expression of the mouse estrogen receptor. Mol. Endocrinol. 1: 735-44 [PMID:2484714]

57. Zhou HB, Sheng S, Compton DR, Kim Y, Joachimiak A, Sharma S, Carlson KE, Katzenellenbogen BS, Nettles KW and Greene GL et al.. (2007) Structure-guided optimization of estrogen receptor binding affinity and antagonist potency of pyrazolopyrimidines with basic side chains. J. Med. Chem. 50: 399-403 [PMID:17228884] 